\title{
Taxonomy of the Lactobacillus acidophilus Group
}

\author{
J. L. JOHNSON, ${ }^{1}$ C. F. PHELPS, ${ }^{1}$ C. S. CUMMINS,' J. LONDON, ${ }^{2}$ AND F. GASSER ${ }^{3}$
}

Anaerobe Laboratory, Virginia Polytechnic Institute and State University, Blacksburg, Virginia 24061'; Microbial Physiology Section, Laboratory of Microbiology and Immunology, National Institute of Dental Research, Bethesda, Maryland 20014 ${ }^{2}$; and Department de Biochimie et Genetique Microbienne, Unite de Physiologie Cellulaire, Institut Pasteur, 75724 Paris, Cedex 15, France ${ }^{3}$

A total of 89 strains designated Lactobacillus acidophilus were examined for physiological properties, type of lactic acid produced, cell wall sugar pattern, guanine plus cytosine content of deoxyribonucleic acid (DNA), and DNA homology values compared with selected reference strains. Immunological reactions among a group of the strains were determined by gel diffusion tests, using antiserum to purified lactic acid dehydrogenase (LDH) from a single strain (Sharpe strain A18). Antiserum to glyceraldehyde-3-phosphate dehydrogenase from strain ATCC 4356 was used in microcomplement fixation tests to determine relationships among some strains. DNA preparations from 78 of the 89 strains of L. acidophilus were distributed among six distinct homology groups, designated A1, A2, A3, A4, B1, and B2. The A group strains had 20 to $30 \%$ intergroup homology but very low homology to groups B1 and B2. Likewise, the strains in the two B groups had 20 to $30 \%$ intergroup homology but very low homology to the A group strains. Nine strains did not fall into any of the six homology groups. The guanine plus cytosine contents of the DNAs in strains comprising the six homology groups varied from 32 to $38 \mathrm{~mol} \%$. In the nine strains not falling into any of the homology groups, the guanine plus cytosine contents were 39 to 47 mol\%. Homology group A1, which includes the neotype strain of L. acidophilus (ATCC 4356), is very homogeneous, with most strains showing $95 \%$ or more homology to the reference strain. This group corresponds to LDH serogroup III. Strains in the other homology groups showed 60 to $90 \%$ homology to their reference strains. Strains of $\mathrm{LDH}$ serogroup II were found in homology groups $\mathrm{A} 2, \mathrm{~A} 3$, and $\mathrm{A} 4$, and those in LDH serogroup I were in homology groups B1 and B2. In general, the glyceraldehyde-3-phosphate dehydrogenase serology results correlated well with the LDH results. Other phenotypic test results were similar for all of the DNA homology groups. It is recommended that homology group A1 be designated $L$. acidophilus and that strain ATCC 4356 remain the neotype strain.

In 1900, Moro isolated from infant feces grampositive, asporogenous rods, which he named Bacillus acidophilus (26). In 1929, this species was included by Holland in the genus Lactobacillus (16). The original strain of Moro was probably lost (13), and its description, according to present day standards, is very incomplete. Moreover, investigators tended to identify all new Lactobacillus isolates from mouths and from intestinal and vaginal floras as strains of Lactobacillus acidophilus. It was only in 1970 that Hansen and Mocquot adequately described this species and designated a neotype strain for it (ATCC 4356) according to the recommendations of the International Subcommittee on the Taxonomy of Lactobacilli and Closely Related Organisms $(13,14)$. The description of $L$. acidophilus by Hansen and Mocquot was derived from the important taxonomic work of Rogosa and Sharpe (29), who based their description of the species on their own observations and on those of Curran et al. (5), Tittsler et al. (35), and Rogosa et al. (30).

The guanine plus cytosine $(\mathrm{G}+\mathrm{C})$ content of the deoxyribonucleic acid (DNA) of several strains of $L$. acidophilus shows a rather good homogeneity, ranging from 34 to $38 \mathrm{~mol} \%$ (11, 12). However, several recent taxonomic investigations have suggested that this species might be heterogeneous. Among strains whose characters were in accord with the species description by Hansen and Mocquot (14), biotypes or groups were described successively on the basis of colonial morphology and substrate fermentations (28), cell width (W. E. C. Moore, personal communication), serological properties (6), cell wall antigens $(32,33)$, and electrophoretic and antigenic characteristics of $\mathrm{D}$ - and L-lactic acid dehydrogenases (LDH) $(7,9)$.

Preliminary DNA homology results indicated 
that a genetic diversity existed among strains identified as members of $L$. acidophilus. These differences appeared to correlate with some of the immunological results. Therefore, our study was expanded to include additional culture collection strains of $L$. acidophilus, more of the strains that had been investigated immunologically, and some recently isolated strains from the collection of the Anaerobe Laboratory, Virginia Polytechnic Institute and State University (VPI), Blacksburg. Phenotypic properties were determined for all of the strains, cell wall sugars were determined for many of them, and immunological relationships of LDH and glyceraldehyde-3-phosphate dehydrogenase (GA3PDH) enzymes were determined for representative strains from each DNA homology group.

\section{MATERIALS AND METHODS}

Bacterial strains. The Lactobacillus strains employed in this study are listed in Table 1. Strains designated with a VPI number only were either sent to the Anaerobe Laboratory for identification or were isolated at this laboratory. This table contains the reference collection abbreviations and numbers for those strains received from national culture collections or just strain numbers for strains obtained from personal collections. There appears to have been some confusion with some of the strains. For example, VPI strains 11084,11085 , and 11086 have all been crossreferenced as NCTC 1950 in culture collection catalogs. Numbers 11084 and 11085 may well represent the same strain since both are in homology group A-1; however, strain 11086 belongs to homology group A-2. Several of the strains were originally obtained from the American Type Culture Collection (ATCC) (VPI strains 0324, 0325, 0326, 0328, 0331, 0333, 11085, 11091, and 11093) but are no longer listed in the catalog of the ATCC.

Physiological properties. The physiological properties of the organisms were determined by $\mathrm{L}$. $\mathrm{V}$. Holdeman and W. E. C. Moore (15), and the isomers of the lactic acid produced were determined by $\mathrm{E}$. Cato by a previously described method (15). All of the media used in these tests contained $0.1 \%$ Tween 80 .

DNA isolation, G+C ratios, and DNA homologies. Each organism was grown in 2.5 liters of medium. The medium contained mineral salts (15), 1\% Trypticase, $0.5 \%$ yeast extract, $1 \%$ glucose, $0.01 \%$ heme, $0.05 \%$ Tween 80 , and $0.05 \mathrm{M}$ potassium phosphate buffer (pH 7.0) and was prepared as described previously (4). For labeling of DNA, the yeast extract concentration was lowered to $0.05 \%$, and $0.5 \mathrm{mCi}$ of either $\left[{ }^{3} \mathrm{H}\right]-$ thymidine or $\left[{ }^{3} \mathrm{H}\right]$ adenine (New England Nuclear Corp., Boston, Mass.) was added to $40 \mathrm{ml}$ of the medium.

Harvested cells were suspended in sodium chlorideethylenediaminetetraacetic acid buffer, pH 8.0 (23), and were physically disrupted by shaking with glass beads (diameter, 0.074 to $0.105 \mathrm{~mm}$; type IV C; Cataphote Corp., Jackson, Miss.) in a Braun cell disintegrator. The cells were shaken for $5 \mathrm{~min}$ at 4,000 cycles per min. The disrupted cells were separated from the glass beads by filtration through a coarse scintered glass filter, and sodium dodecyl sulfate (final concentration, $1 \%$ ) and $50 \mu \mathrm{g}$ of pronase (Calbiochem, La Jolla, Calif.) per $\mathrm{ml}$ were added. After incubation at $56^{\circ} \mathrm{C}$ for $1 \mathrm{~h}$, the cell walls were removed by centrifugation. The cell walls were saved for sugar analysis (see below), and the supernatant was extracted with phenol. From this point the hydroxylapatite procedure was used for DNA isolation, as previously described (20).

The $\mathrm{G}+\mathrm{C}$ content of each DNA preparation was calculated from the thermal melting temperature. The thermal melting temperature values were determined by using a Gilford model 2400 spectrophotometer equipped with a model 2527 thermal programmer. Details of the procedure have been published previously $(21,24)$.

The unlabeled DNA preparations, which were dissolved in $0.02 \mathrm{M} \mathrm{NaCl}-10^{-3} \mathrm{M}$ HEPES $(N-2$ hydroxyethylpiperazine- $N^{\prime}$-2-ethanesulfonic acid; $\mathrm{pH} 7.0$ ), were further fragmented by sonic oscillation. Each preparation was sonicated for two 30 -s periods by a Biosonik III (Bronwill Scientific Inc., Rochester, N.Y.) instrument fitted with a 0.375 -inch (ca. $0.95-\mathrm{cm}$ ) diameter tip and at an energy setting of $60 \%$. The DNA preparations were then denatured, and any contaminating ribonucleic acid was hydrolyzed by the addition of $5 \mathrm{~N} \mathrm{NaOH}$ to a final concentration of $0.25 \mathrm{~N}$. After heating for $15 \mathrm{~min}$ at $50^{\circ} \mathrm{C}$, the preparations were cooled, and the $\mathrm{NaOH}$ was neutralized with $5 \mathrm{~N} \mathrm{HCl}$. The DNA preparations were then dialyzed overnight against $0.02 \mathrm{M} \mathrm{NaCl}-10^{-3} \mathrm{M}$ HEPES buffer (pH 7.0) and then adjusted to $0.6 \mathrm{mg} / \mathrm{ml}$. The labeled DNA preparations were prepared in the same manner, except that the DNA was fragmented by two passages through a French pressure cell at a pressure of 1.1 kbar and the final DNA concentration was adjusted to $0.01 \mathrm{mg} / \mathrm{ml}$.

DNA homology experiments were performed by a variation of the $S 1$ nuclease procedure as described by Crosa et al. (3). Free solution reassociation reactions were carried out by using vials ( 6 by $25 \mathrm{~mm}$ ) which were capped with the insertion part of serum bottle stoppers. The reaction mixtures each contained $10 \mu \mathrm{l}$ $(0.1 \mu \mathrm{g})$ of labeled DNA, $50 \mu \mathrm{l}(30 \mu \mathrm{g})$ of unlabeled DNA (either homologous, heterologous bacterial, or native fragmented salmon sperm DNA), and $50 \mu \mathrm{l}$ of $0.88 \mathrm{M} \mathrm{NaCl}-10^{-3} \mathrm{M}$ HEPES buffer (pH 7.0). Just before each experiment, the amount of labeled DNA needed for the experiment was denatured a second time by heating the tube in a boiling water bath for 2 to $3 \mathrm{~min}$. The reaction vials containing native salmon sperm DNA were used to measure the amount of self renaturation of labeled DNA during the incubation period. The reaction vials were incubated for $16 \mathrm{~h}$ at a temperature $25^{\circ} \mathrm{C}$ below the thermal melting temperature of the reference DNA (as measured in 0.15 $\mathrm{M} \mathrm{NaCl}-0.015 \mathrm{M}$ sodium citrate buffer, $\mathrm{pH}$ 7.0). After incubation, a 100- $\mu$ sample was removed from each vial and transferred into a test tube (13 by $100 \mathrm{~mm}$ ) for $\mathrm{S} 1$ nuclease digestion.

The S1 nuclease was either prepared from crude amylase powder (type IVA; Sigma Chemical Co., St. Louis, Mo.) by the method of Vogt (36) but with no further purification after elution from the diethyl- 
TABLE 1. List of strains used in this study

\begin{tabular}{lll}
\hline VPI no. & Other no. & Source and other comments \\
\hline Homology Group A-1 & \\
6032 & ATCC 4356 & Human, neotype strain, strain scav, NCIB 8690 \\
0331 & ATCC 4796 & E. B. Fred L.d.4 \\
$0330^{a}$ & ATCC 4357 & Human, Kulp strain PAK \\
0328 & ATCC 4355 & Rat, Kulp strain R-1-1 \\
0326 & ATCC 832 & Rat, L. F. Rettger 4B, NCIB 1723 \\
0324 & ATCC 314 & Human, E. O. Jordan, L. F. Rettger 43 \\
$11084^{b}$ & NCTC 1899 & Strain 2 Kopeloff, ATCC 11975, NCTC 1950, NCIB 1899 \\
$11085^{b 1}$ & ATCC 11975 & NCIB 1899, NCTC 1899 \\
11091 & ATCC 9224 & M. Rogosa L. jugerti \\
$11096^{a 1}$ & NCIB 8607 & Strain PAK, ATCC 4357 \\
11473 & & Inoculum for sweet acidophilus milk \\
11566 & & Sweet acidophilus milk \\
11695 & SA18 & F. Gasser, M. E. Sharpe A18 \\
$11760^{c}$ & NCDO 1 & M. E. Sharpe A1 \\
$11843^{c 1}$ & A1 & M. E. Sharpe \\
12596 & YIT 0165 & H. Shimohashi, fermented milk
\end{tabular}

Homology group A-2

1784

1799

11083

0607-1B

$11086^{b 2}$

11082

6272

11090

6317

7635

11697

11845

11761

NCTC 2949

NCIB 4505

NCTC 4504

NCIB 8821

SA 5

A 4

SA 11

Homology group A-3

1754

0818

1756

0824

0773

0673

1830

P9A-27

P10B-17

Homology group A-4

1294

1793

2164A
Chicken cecum

Chicken crop

Cruickshank V.3, human vagina

Unknown

(Strain 7, NCTC 4505, NCDO 5) NCTC 1950

Cruickshank strain 2, NCIB 4504, NCDO 4

Human, cervical vagina

Strain Hayward $1 F$, human saliva

Human, cervical vagina

Human, urine

F. Gasser, M. E. Sharpe A5

M. E. Sharpe

F. Gasser, M. E. Sharpe A11
Hog, small intestine

Hog, small intestine

Hog, small intestine

Hog, small intestine

Hog, small intestine

Hog, small intestine

Chicken crop

Hog, stomach

Hog, small intestine

Chicken crop

Chicken large intestine

Turkey cecum (with enteritis) 
TABLE 1. Continued

\begin{tabular}{lll}
\hline VPI no. & Other no. & Source and other comments \\
\hline Homology group B-1 & \\
6033 & ATCC 19992 & Feces, P. A. Hansen ISL 4, G. Re \\
0334 & ATCC 4963 & Human, L. F. Rettger 5 \\
11092 & NCIB 8820 & Strain Hayward 1C, ATCC 29601 \\
11087 & NCIB 8819 & Strain Hayward 1A, human saliva \\
0333 & ATCC 4962 & L. F. Rettger 3 \\
11089 & ATCC 9857 & Döderlein's bacillus, NCTC 2948 \\
$6099 B$ & & Human, stomach \\
9395 & & Human, abdominal wound \\
$7978 C$ & & Human, throat fistula \\
6325 & & Human, cervical vagina \\
6077 & & Human, stomach \\
6322 & & Human, cervical vagina \\
7763 & & Human, vaginal swab \\
$6364 \mathrm{~A}$ & & Human, cervical vagina \\
6324 & & Human, cervical vagina \\
7227 & & Human, urine \\
0657 & CDC 1191 & Human, blood \\
7677 & & Human, gastrostomy \\
9940 & & D. W. Lambe, 1464-74B \\
8832 & & Human, pelvis pus \\
6101 & & Human, stomach, sprue \\
11757 & $65 \mathrm{~K}$ & F. Gasser \\
11759 d & NCDO3 & M. E. Sharpe \\
$1184 d^{2} 1$ & A3 & M. E. Sharpe \\
12598 & LA-2 & H. Shimohashi, human feces \\
12599 & LA-3 & H. Shimohashi, human feces \\
12601 & YIT-0164 & H. Shimohashi, fermented milk \\
& &
\end{tabular}

Homology group B-2

7893A

7960

0779

0325

ATCC 332

11088

11694

11696

11846

ATCC 11506

SA20

$63 \mathrm{E}$

12597

A21

12600

RA-69

12602

RA-3

12603

RA-42

RA-22

Human, sinus drainage pus

Human, blood

Hog cecum

L. A. Rogers (USDA), L. F. Rettger

NCIB 8795, NCIB 8892

F. Gasser

F. Gasser

M. E. Sharpe

H. Shimohashi, rat intestinal tract

H. Shimohashi, rat intestinal tract

H. Shimohashi, rat intestinal tract

H. Shimohashi, rat intestinal tract

Other L. acidopbilus like organisms

0776

1309

1395

1796

8409

9412

11093

11094

11095
ATCC 4913

NCTC 1406

NCTC 1407

\section{Hog cecum}

Chicken, small intestine

Dog, small intestine

Chicken crop

Mouse cecum

Bovine rumen

E. McCoy L.d.3, L. acidophilus, amino acid assay

Type 1, Lactobacillus acidopbilus-odontolyticus

Type 2, Lactobacillus acidopbilus-odontolyticus 
TABLE 1. Continued

\begin{tabular}{lll} 
VPI no. & Other no. & Source and other comments \\
\hline $\begin{array}{lll}\text { Other species } & & \\
6044 & \text { ATCC } 15009 & \text { Neotype strain Lactobacillus belveticus } \\
11343 & \text { ATCC } 25258 & \text { Type strain Lactobacillus jensenii }\end{array}$
\end{tabular}

${ }^{a}$ Numbers with superscripts $a$ and $a l$ represent a single strain.

${ }^{b}$ Numbers with superscripts $b, b 1$, and $b 2$ represent a single strain.

'Numbers with superscripts $c$ and $c l$ represent a single strain.

${ }^{d}$ Numbers with superscripts $d$ and $d l$ represent a single strain.

aminoethyl column or purchased from Calbiochem. In either case, the nuclease activities were titrated by using $50 \mu \mathrm{l}$ of twofold dilutions of the enzyme preparations to degrade $30 \mu \mathrm{g}$ of denatured DNA in $1.0-\mathrm{ml}$ volumes of $0.05 \mathrm{M}$ sodium acetate- $0.3 \mathrm{M}$ sodium chloride-0.5 mM zinc chloride buffer, $\mathrm{pH} 4.6$ (31). Digestion was for $1 \mathrm{~h}$ at $50^{\circ} \mathrm{C}$. All assays were then performed by using the enzyme at twice the concentration required for effective hydrolysis of $30 \mu \mathrm{g}$ of singlestranded DNA.

In addition to the sample of reassociation mixture, each digestion tube contained $1.0 \mathrm{ml}$ of the sodium acetate-sodium chloride-zinc chloride buffer, $25 \mu \mathrm{g}$ of fragmented, denatured salmon sperm DNA, and $50 \mu \mathrm{l}$ of $\mathrm{S} 1$ nuclease. After incubation for $1 \mathrm{~h}$ at $50^{\circ} \mathrm{C}$, an equal volume of $10 \%$ trichloroacetic acid was added to each tube. The tubes were cooled in a refrigerator at $4^{\circ} \mathrm{C}$ for at least $1 \mathrm{~h}$, and the precipitates were collected on nitrocellulose membrane filters (BA85; Schleicher \& Schuell Co., Keene, N.H.). The membranes were dried, and the radioactivity was measured with a liquid scintillation counter and a toluene-based scintillation fluid.

Cell wall analysis. The methods for the preparation of purified cell walls and determination of cell wall sugars have been described previously (4).

Immunological procedures. (i) GA3PDH. An electrophoretically homogeneous preparation of GA3PDH was prepared from $L$. acidophilus ATCC 4356 by an adaptation of a procedure used to purify the same enzyme from Streptococcus faecalis (N. M. Chace and J. London, Abstr. Annu. Meet. Am. Soc. Microbiol. 1975, K48, p. 155). High-titer antiserum was produced in a pair of 6-month-old Australian white rabbits by a series of four weekly intradermal injections of a suspension containing $0.178 \mathrm{mg}$ of GA3PDH, $20 \mu \mathrm{g}$ of methylated bovine serum albumin, and $0.2 \mathrm{ml}$ of complete Freund adjuvant in a final volume of 0.6 $\mathrm{ml}$. The intradermal injections were followed by three intravenous injections given 1 week apart and consisting of $0.148 \mathrm{mg}$ of enzyme plus $20 \mu \mathrm{g}$ of methylated bovine serum albumin. At 5 days after the final injection, the rabbits were bled from the central ear artery, and $40 \mathrm{ml}$ of blood was collected. After standing overnight at $4^{\circ} \mathrm{C}$, the clotted erythrocytes and fibrin were separated from the plasma by centrifugation, and the clarified serum was stored as $5-\mathrm{ml}$ volumes at $-40^{\circ} \mathrm{C}$.

Immunodiffusion experiments were carried out according to the Stollar and Levine (34) modification of the Ouchterlony technique. Details of these experi- ments are presented elsewhere (22). The convention of Gasser and Gasser (9) was used to summarize immunodiffusion results. Interpretation of these results has also been described previously (22).

Microcomplement fixation experiments were performed by the procedure of Wasserman and Levine (37); minor modifications of this technique have been described elsewhere (22). The GA3PDH antiserum was used at a dilution of $1: 120,000$ to $1: 150,000$ with the homologous antigen; the latter was employed in the range of 1 to $10 \mu \mathrm{g}$ of protein. Heterologous antigen was used in the range of 0.5 to $50 \mu \mathrm{g}$. The relative amounts of complement fixed by both homologous and heterologous antigens were linear and paralleled functions of the logarithm of the antibody concentration. Therefore, results of the experiments with different antigens were directly comparable (31). The index of dissimilarity for each heterologous aldolase was calculated from those data by the equation of Cham. pion et al. (2). For the anti-L. acidophilus GA3PDH, the term $m$ of their equation equaled 247. Data are also expressed as immunological distance units; these are derived by multiplying the log of the index of dissimilarity by 100 (2).

(ii) LDH. The presence of L-LDH and D-LDH (both nicotinamide adenine dinucleotide-dependent and -independent) activity in crude extracts was determined spectophotometrically (7). Immunological groups were determined with immunodiffusion experiments by using antiserum produced against the $\mathrm{L}-\mathrm{LDH}$ of $L$. acidophilus A18 (=VPI 11695) according to a technique described previously $(8,9)$. Each unknown extract was placed into a well next to another reference crude extract. The reference strains and the immunological groups are as follows: group $1,65 \mathrm{~K}(=\mathrm{VPI} 11757)$ and 63E (=VPI 11696); group II, A5 (=VPI 11697) and A11 (=VPI 11761); and group III, A18 (=VPI 11695) and ATCC 4356 (=VPI 6032). Moreover, every unknown crude extract was tested by pairwise comparison against all of the other unknown extracts in order to confirm clearly its appurtenance to group I, II, or III.

\section{RESULTS}

The $\mathrm{G}+\mathrm{C}$ values and the DNA homology results for the $L$. acidophilus group are presented in Table 2. The $\mathrm{G}+\mathrm{C}$ values are in good agreement with those obtained by Gasser and Mandel (11) and by Gasser and Sebald (12) in those cases where the same organisms were examined. 
TABLE 2. DNA homologies among the L. acidophilus group of organisms

\begin{tabular}{|c|c|c|c|c|c|c|c|c|c|c|}
\hline \multirow{2}{*}{ VPI no. } & \multirow[b]{2}{*}{ Other designations } & \multirow{2}{*}{$\begin{array}{c}\mathrm{GC} \\
(\mathrm{mol} \%)\end{array}$} & \multicolumn{8}{|c|}{ Percent homology to: } \\
\hline & & & 6032 & 1784 & 7635 & 1754 & 1294 & 6033 & 6322 & 7960 \\
\hline \multicolumn{11}{|c|}{ Homology Group A-1 } \\
\hline 6032 & ATCC 4356 & 32 & 100 & 35 & 26 & 25 & 19 & 10 & 10 & 6 \\
\hline 0331 & ATCC 4796 & 33 & 100 & 27 & 25 & 22 & 21 & 6 & 10 & 5 \\
\hline 0330 & ATCC 4357 & 32 & 96 & 27 & 23 & 24 & 20 & 11 & 14 & 6 \\
\hline 0328 & ATCC 4355 & 33 & 94 & 28 & 36 & 23 & 20 & 6 & 11 & 2 \\
\hline 0326 & ATCC 832 & 33 & 96 & 28 & 31 & 34 & 22 & 8 & 12 & 2 \\
\hline 0324 & ATCC 314 & 31 & 104 & 15 & 21 & 26 & 18 & 6 & 6 & 6 \\
\hline 11084 & NCTC 1899 & 35 & 99 & 17 & 20 & 27 & 23 & 5 & 7 & 5 \\
\hline 11085 & ATCC 11975 & 36 & 102 & 2 & 20 & 28 & 25 & 5 & 4 & 4 \\
\hline 11091 & ATCC 9224 & 36 & 98 & 20 & 23 & 28 & 25 & 8 & 6 & 0 \\
\hline 11096 & NCIB 8607 & 36 & 97 & 20 & 22 & 30 & 23 & 5 & 4 & -2 \\
\hline 11473 & & 34 & 92 & 24 & 22 & 34 & 24 & 6 & 6 & 11 \\
\hline 11566 & & 34 & 102 & 26 & 23 & 30 & 24 & 9 & 9 & 15 \\
\hline 11695 & SA18 & 37 & 87 & 18 & 21 & 35 & 20 & $\mathbf{0}$ & 8 & 1 \\
\hline 11760 & NCDO1 & 34 & 93 & 7 & 22 & 34 & 23 & 13 & 10 & 15 \\
\hline 11843 & & 33 & 97 & 18 & 25 & 32 & 29 & 7 & 5 & 3 \\
\hline 12596 & YIT 0165 & 34 & 95 & 14 & 19 & 24 & 21 & 5 & 6 & 10 \\
\hline \multicolumn{11}{|c|}{ Homology Group A-2 } \\
\hline 1784 & & 35 & 29 & 100 & 71 & 22 & 18 & 8 & 10 & 0 \\
\hline 1799 & & 36 & 23 & 93 & 76 & 27 & 24 & 9 & 10 & 2 \\
\hline 11083 & NCTC 2949 & 38 & 26 & 69 & 70 & 23 & 24 & 4 & 5 & 7 \\
\hline 0607-1B & CDC & 35 & 23 & 65 & 60 & 21 & 21 & 8 & 9 & 5 \\
\hline 11082 & NCTC 4504 & 38 & 22 & 62 & 66 & 20 & 24 & 9 & 8 & 0 \\
\hline 11086 & NCIB 4505 & 37 & 23 & 62 & 70 & 22 & 24 & 3 & 7 & 0 \\
\hline 6272 & & 35 & 21 & 60 & 78 & 20 & 20 & 10 & 8 & 2 \\
\hline 11090 & NCIB 8821 & 38 & 22 & 59 & 72 & 24 & 21 & 9 & 8 & 4 \\
\hline 6317 & & 37 & 20 & 57 & 69 & 19 & 17 & 6 & 7 & 0 \\
\hline 7635 & & 36 & 21 & 57 & 100 & 18 & 24 & 5 & 8 & 6 \\
\hline 11697 & SA5 & 36 & 26 & 43 & 72 & 28 & 26 & 10 & 8 & 10 \\
\hline 11845 & A4 & 35 & 14 & 66 & 71 & 28 & 23 & 6 & 9 & 3 \\
\hline 11761 & SA11 & & 23 & 63 & 71 & 28 & 16 & 1 & 8 & 4 \\
\hline \multicolumn{11}{|c|}{ Homology Group A-3 } \\
\hline 1754 & & 38 & 29 & 16 & 31 & 100 & 27 & 8 & 10 & 9 \\
\hline 0818 & & 36 & 27 & 17 & 26 & 88 & 29 & 7 & 8 & 7 \\
\hline 1756 & & 34 & 31 & 32 & 36 & 86 & 31 & 5 & 10 & 4 \\
\hline 0824 & & 36 & 27 & 30 & 33 & 84 & 30 & 4 & 9 & 2 \\
\hline 0773 & & & 26 & 12 & 20 & 84 & 25 & 6 & 3 & 3 \\
\hline 0673 & & 38 & 21 & 17 & 20 & 80 & 25 & 6 & 4 & 4 \\
\hline 1830 & & & 26 & 14 & 27 & 64 & 33 & 6 & 8 & 8 \\
\hline P9A-27 & & 37 & 25 & 17 & 24 & 72 & 32 & 7 & 7 & 8 \\
\hline P10B-17 & & 38 & 28 & 21 & 25 & 81 & 32 & 6 & 6 & 11 \\
\hline \multicolumn{11}{|c|}{ Homology Group A-4 } \\
\hline 1294 & & & 27 & 13 & 22 & 30 & 100 & 5 & 5 & 7 \\
\hline 1793 & & & 23 & 16 & 26 & 29 & 81 & 5 & 5 & 7 \\
\hline $2164 A$ & & & 26 & 31 & 23 & 26 & 72 & 5 & 12 & 4 \\
\hline \multicolumn{11}{|c|}{ Homology Group B-1 } \\
\hline 6033 & ATCC 19992 & 33 & 9 & 11 & 14 & 6 & 6 & 100 & 64 & 32 \\
\hline 0334 & ATCC 4963 & 34 & 13 & 12 & 21 & 7 & 8 & 88 & 65 & 34 \\
\hline 11092 & NCIB 8820 & 35 & 11 & 9 & 9 & 9 & 8 & 85 & 56 & 32 \\
\hline 11087 & NCIB 8819 & 35 & 10 & 6 & 10 & 7 & 9 & 83 & 57 & 32 \\
\hline 0333 & ATCC 4962 & 33 & 11 & 12 & 20 & 9 & 7 & 80 & 68 & 33 \\
\hline 11089 & ATCC 9857 & 35 & 11 & 12 & 10 & 9 & 8 & 79 & 55 & 20 \\
\hline 6099B & & 33 & 16 & 9 & 18 & 2 & 8 & 75 & 72 & 32 \\
\hline 9395 & & 33 & 7 & 2 & 16 & 2 & 8 & 87 & 57 & 35 \\
\hline $7978 \mathrm{C}$ & & 33 & 6 & 4 & 12 & 6 & 7 & 77 & 55 & 33 \\
\hline 6325 & & 34 & 14 & 4 & 15 & 3 & 12 & 71 & 57 & 40 \\
\hline 6077 & & 34 & 17 & 10 & 11 & 4 & 10 & 70 & 64 & 31 \\
\hline 6322 & & 33 & 15 & 13 & 28 & 9 & 11 & 63 & 100 & 39 \\
\hline 7763 & & 32 & 9 & 9 & 16 & 4 & 7 & 58 & 92 & 33 \\
\hline 6364 & & 33 & 9 & 1 & 14 & 5 & 10 & 56 & 92 & 32 \\
\hline 6324 & & 33 & 8 & 2 & 14 & 4 & 10 & 57 & 91 & 36 \\
\hline 7227 & & 33 & 9 & 1 & 19 & 4 & 11 & 59 & 88 & 37 \\
\hline 0657 & & 33 & 7 & 5 & 10 & 0 & 6 & 64 & 81 & 35 \\
\hline
\end{tabular}


TABLE 2. Continued

\begin{tabular}{|c|c|c|c|c|c|c|c|c|c|c|}
\hline \multirow[b]{2}{*}{ VPI no. } & \multirow[b]{2}{*}{ Other designations } & \multirow{2}{*}{$\begin{array}{c}\text { GC } \\
(\mathrm{mol} \%)\end{array}$} & \multicolumn{7}{|c|}{ Percent homology to: } & \multirow[b]{2}{*}{7960} \\
\hline & & & 6032 & 1784 & 7635 & 1754 & 1294 & 6033 & 6322 & \\
\hline $\begin{array}{l}7677 \\
12598 \\
12601 \\
9940 \\
8832 \\
6101 \\
11757 \\
11759 \\
11844 \\
12599\end{array}$ & $\begin{array}{l}\text { LA-2 } \\
\text { YIT-0164 } \\
\\
\\
65 \mathrm{~K} \\
\text { NCDO3 } \\
\text { A3 } \\
\text { LA-3 }\end{array}$ & $\begin{array}{l}35 \\
35 \\
32 \\
34 \\
34 \\
\\
\\
34 \\
33\end{array}$ & $\begin{array}{r}16 \\
4 \\
8 \\
10 \\
7 \\
8 \\
9 \\
11 \\
0 \\
0\end{array}$ & $\begin{array}{r}9 \\
6 \\
4 \\
11 \\
4 \\
2 \\
17 \\
1 \\
3 \\
3\end{array}$ & $\begin{array}{r}24 \\
8 \\
8 \\
19 \\
16 \\
19 \\
11 \\
11 \\
10 \\
8\end{array}$ & $\begin{array}{r}5 \\
12 \\
9 \\
11 \\
1 \\
4 \\
12 \\
10 \\
8 \\
1\end{array}$ & $\begin{array}{r}6 \\
8 \\
8 \\
12 \\
8 \\
10 \\
9 \\
11 \\
6 \\
8\end{array}$ & $\begin{array}{l}60 \\
87 \\
73 \\
68 \\
58 \\
53 \\
77 \\
70 \\
81 \\
61\end{array}$ & $\begin{array}{l}76 \\
53 \\
60 \\
66 \\
67 \\
68 \\
62 \\
52 \\
57 \\
81\end{array}$ & $\begin{array}{l}31 \\
33 \\
39 \\
36 \\
35 \\
36 \\
44 \\
45 \\
34 \\
34\end{array}$ \\
\hline $\begin{array}{l}\text { Homolo } \\
7893 \mathrm{~A} \\
7960 \\
0779 \\
0325 \\
11088 \\
11694 \\
11696 \\
11846 \\
12597 \\
12600 \\
12602 \\
12603\end{array}$ & $\begin{array}{l}\text { ATCC } 332 \\
\text { ATCC } 11506 \\
\text { SA 20 } \\
63 \mathrm{E} \\
\text { A21 } \\
\text { RA-69 } \\
\text { RA-3 } \\
\text { RA-42 } \\
\text { RA-22 }\end{array}$ & $\begin{array}{l}33 \\
33 \\
32 \\
33 \\
32 \\
30 \\
36 \\
\\
32 \\
33 \\
33 \\
34\end{array}$ & $\begin{array}{r}7 \\
8 \\
7 \\
11 \\
6 \\
15 \\
15 \\
10 \\
10 \\
6 \\
10 \\
0\end{array}$ & $\begin{array}{r}1 \\
2 \\
4 \\
9 \\
10 \\
8 \\
1 \\
4 \\
4 \\
6 \\
3 \\
5\end{array}$ & $\begin{array}{r}11 \\
18 \\
6 \\
14 \\
5 \\
11 \\
11 \\
8 \\
8 \\
9 \\
10 \\
10\end{array}$ & $\begin{array}{r}1 \\
0 \\
3 \\
6 \\
4 \\
11 \\
15 \\
10 \\
9 \\
5 \\
8 \\
3\end{array}$ & $\begin{array}{c}5 \\
7 \\
8 \\
5 \\
5 \\
9 \\
8 \\
5 \\
8 \\
7 \\
9 \\
11\end{array}$ & $\begin{array}{c}32 \\
32 \\
28 \\
29 \\
18 \\
36 \\
33 \\
25 \\
39 \\
33 \\
29 \\
35\end{array}$ & $\begin{array}{l}24 \\
27 \\
24 \\
36 \\
22 \\
30 \\
30 \\
34 \\
29 \\
27 \\
25 \\
29\end{array}$ & $\begin{array}{r}98 \\
100 \\
78 \\
75 \\
67 \\
79 \\
88 \\
73 \\
72 \\
70 \\
61 \\
70\end{array}$ \\
\hline $\begin{array}{l}\text { Other } \\
0776 \\
1309 \\
1395 \\
1796 \\
8409 \\
9412 \\
11093 \\
11094 \\
11095 \\
6044 \\
11343\end{array}$ & $\begin{array}{l}\text { ATCC } 4913 \\
\text { NCTC } 1406 \\
\text { NCTC } 1407 \\
\text { ATCC } 15009 \\
\text { ATCC } \mathbf{2 5 2 5 8}\end{array}$ & $\begin{array}{l}47 \\
40 \\
41 \\
43 \\
39 \\
\\
49 \\
44 \\
46 \\
37 \\
31\end{array}$ & $\begin{array}{r}0 \\
3 \\
13 \\
4 \\
1 \\
3 \\
0 \\
2 \\
1 \\
13 \\
11\end{array}$ & $\begin{array}{r}0 \\
5 \\
1 \\
1 \\
0 \\
0 \\
3 \\
3 \\
3 \\
25 \\
4\end{array}$ & $\begin{array}{r}10 \\
16 \\
6 \\
6 \\
4 \\
8 \\
5 \\
4 \\
5 \\
21 \\
7\end{array}$ & $\begin{array}{r}1 \\
2 \\
0 \\
1 \\
0 \\
3 \\
6 \\
4 \\
2 \\
18 \\
7\end{array}$ & $\begin{array}{r}4 \\
7 \\
3 \\
5 \\
3 \\
5 \\
5 \\
6 \\
3 \\
44 \\
7\end{array}$ & $\begin{array}{r}4 \\
13 \\
0 \\
1 \\
0 \\
0 \\
1 \\
0 \\
3 \\
6 \\
8\end{array}$ & $\begin{array}{r}3 \\
14 \\
5 \\
3 \\
2 \\
2 \\
0 \\
0 \\
0 \\
8 \\
6\end{array}$ & $\begin{array}{r}0 \\
29 \\
0 \\
1 \\
0 \\
0 \\
0 \\
0 \\
0 \\
6 \\
7\end{array}$ \\
\hline
\end{tabular}

The range of $\mathrm{G}+\mathrm{C}$ values for a given DNA homology group appears to be greater than for other microorganisms that we have investigated. These variations may have been due to subtle differences in the DNA preparations, such as varying amounts of contaminating polysaccharide or teichoic acid or endogenous deoxyribonuclease activity, which may have slightly influenced some of the thermal melting temperature values. In homology group A-1, for example, DNA preparations ranging from 31 to $36 \mathrm{~mol} \%$ $\mathrm{G}+\mathrm{C}$ all had essentially $100 \%$ homology to reference strain 6032 , so there is no reason to believe that there are real differences in the $\mathrm{G}+\mathrm{C}$ values among strains within a DNA homology group.

DNA preparations from the $L$. acidophilus group are distributed among six distinct homology groups (Table 2). The first four, designated A-1, A-2, A-3, and A-4, had 20 to $30 \%$ intergroup homology but very low homology to the other two groups, B-1 and B-2. Likewise, DNA preparations from organisms in the B-1 and B-2 homology groups had 20 to $30 \%$ DNA homology to each other and very low homology to the four A groups.

Nine strains phenotypically similar to $L$. acidophilus were also included in the homology study. DNA from most of these organisms had higher $\mathrm{G}+\mathrm{C}$ values than did DNA from the $L$. acidophilus group, and the DNA preparations had little or no homology to any of the reference DNA preparations.

The physiological properties of the 89 strains used in this study are presented in Table 3 . All of the strains produced major amounts of lactic acid, moderate amounts of acetic acid, no hydrogen, and no catalase. Growth of all of the strains was enhanced by a fermentable carbohydrate, and all fermented cellobiose, fructose, glucose, and maltose and hydrolyzed esculin. None of the strains fermented inositol, produced indole, $\mathrm{H}_{2} \mathrm{~S}$, lipase, lecithinase, or urease, or digested gelatin, milk, or meat. None of the strains attacked threonine or arabinose galactan. Two of the nine phenotypically similar strains were motile. All 
TABLE 3. Physiological characteristics of L. acidophilus homology groups

\begin{tabular}{|c|c|c|c|c|c|c|c|}
\hline Characteristic $^{d}$ & $\mathrm{~A}-1(16)^{a}$ & A-2(13) & $A-3(9)$ & $A-4(3)$ & B-1(27) & B-2(12) & Others $(9)$ \\
\hline Formic acid detected & $3 / 16^{b}$ & $0 / 13$ & $1 / 9$ & $1 / 3$ & $1 / 27$ & $1 / 12$ & $0 / 9$ \\
\hline Succinic acid detected & $13 / 16$ & $13 / 13$ & $9 / 9$ & $3 / 3$ & $23 / 27$ & $10 / 12$ & $5 / 9$ \\
\hline Amygdalin & $15 / 16$ & $7 / 13$ & $7 / 9$ & $1 / 3$ & $27 / 27$ & $8 / 12$ & $4 / 9$ \\
\hline Arabinose & $1 / 16$ & $0 / 13$ & $0 / 9$ & $1 / 3$ & $0 / 27$ & $0 / 12$ & $2 / 9$ \\
\hline Erythritol & $0 / 16$ & $2 / 13$ & $0 / 9$ & $0 / 3$ & $2 / 27$ & $1 / 12$ & $0 / 9$ \\
\hline Esculin & $13 / 16$ & $13 / 13$ & $7 / 9$ & $3 / 3$ & $25 / 27$ & $11 / 12$ & $7 / 9$ \\
\hline Glycogen & $16 / 16$ & $8 / 16$ & $2 / 9$ & $2 / 3$ & $2 / 27$ & $1 / 12$ & $0 / 8$ \\
\hline Lactose & $15 / 16$ & $13 / 13$ & $9 / 9$ & $2 / 3$ & $27 / 27$ & $12 / 12$ & $8 / 9$ \\
\hline Mannitol & $0 / 16$ & $0 / 13$ & $1 / 9$ & $0 / 3$ & $0 / 27$ & $1 / 12$ & $3 / 9$ \\
\hline Mannose & $16 / 16$ & $13 / 13$ & $9 / 9$ & $3 / 3$ & $26 / 27$ & $12 / 12$ & $9 / 9$ \\
\hline Melezitose & $1 / 16$ & $1 / 13$ & $0 / 9$ & $0 / 3$ & $3 / 27$ & $2 / 12$ & $1 / 9$ \\
\hline Melibiose & $9 / 16$ & $9 / 13$ & $6 / 9$ & $1 / 3$ & $2 / 27$ & $6 / 12$ & $8 / 9$ \\
\hline Pectin & $2 / 14$ & $2 / 12$ & $0 / 7$ & $0 / 3$ & $2 / 24$ & $2 / 10$ & $1 / 9$ \\
\hline Raffinose & $11 / 16$ & $11 / 13$ & $7 / 9$ & $3 / 3$ & $1 / 27$ & $6 / 12$ & $7 / 9$ \\
\hline Rhamnose & $1 / 16$ & $0 / 13$ & $0 / 9$ & $0 / 3$ & $0 / 27$ & $0 / 12$ & $1 / 9$ \\
\hline Ribose & $2 / 16$ & $1 / 13$ & $0 / 9$ & $0 / 3$ & $1 / 27$ & $0 / 12$ & $6 / 9$ \\
\hline Salicin & $15 / 16$ & $13 / 13$ & $9 / 9$ & $3 / 3$ & $27 / 27$ & $12 / 12$ & $9 / 9$ \\
\hline Sorbitol & $0 / 16$ & $0 / 13$ & $0 / 9$ & $0 / 3$ & $2 / 27$ & $0 / 12$ & $0 / 9$ \\
\hline Starch & $13 / 16$ & $13 / 13$ & $9 / 9$ & $3 / 3$ & $27 / 27$ & $11 / 12$ & $2 / 9$ \\
\hline Starch hydrol. & $4 / 16$ & $10 / 13$ & $9 / 9$ & $3 / 3$ & $12 / 27$ & $0 / 12$ & $7 / 9$ \\
\hline Sucrose & $16 / 16$ & $13 / 13$ & $9 / 9$ & $3 / 3$ & $27 / 27$ & $12 / 12$ & $7 / 9$ \\
\hline Trehalose & $14 / 16$ & $9 / 13$ & $1 / 9$ & $0 / 3$ & $27 / 27$ & $10 / 12$ & $6 / 9$ \\
\hline Xylan & $1 / 14$ & $9 / 13$ & $2 / 7$ & $1 / 2$ & $1 / 24$ & $0 / 7$ & $0 / 8$ \\
\hline Xylose & $1 / 16$ & $2 / 13$ & $0 / 9$ & $0 / 3$ & $4 / 27$ & $3 / 12$ & $0 / 9$ \\
\hline Milk curd & $15 / 16$ & $13 / 13$ & $9 / 9$ & $1 / 3$ & $25 / 27$ & $12 / 12$ & $7 / 9$ \\
\hline $\mathrm{NO}_{3}$ reduced & $1 / 16$ & $0 / 11$ & $0 / 9$ & $0 / 3$ & $0 / 27$ & $0 / 12$ & $2 / 9$ \\
\hline Good growth in bile & $4 / 16$ & $6 / 10$ & $5 / 7$ & $2 / 3$ & $9 / 21$ & $6 / 12$ & $4 / 9$ \\
\hline Hemolysis (alpha or atipical B) & $3 / 9$ & $6 / 11$ & $6 / 7$ & $2 / 3$ & $19 / 26$ & $6 / 12$ & $5 / 9$ \\
\hline Gas (trace-moderate) & $5 / 15$ & $8 / 12$ & $7 / 9$ & $2 / 3$ & $18 / 27$ & $7 / 12$ & $7 / 9$ \\
\hline $\mathrm{NH}_{3}$ from arginine & $2 / 15$ & $0 / 12$ & $1 / 9$ & $0 / 3$ & $1 / 27$ & $0 / 12$ & $0 / 9$ \\
\hline Clindamycin resistant ${ }^{c}$ & $6 / 14$ & $0 / 11$ & $0 / 7$ & $0 / 2$ & $14 / 26$ & $0 / 12$ & $0 / 8$ \\
\hline Penicillin G resistant ${ }^{c}$ & $0 / 14$ & $4 / 11$ & $5 / 7$ & $2 / 2$ & $1 / 26$ & $0 / 12$ & $2 / 8$ \\
\hline Tetracycline resistant ${ }^{c}$ & $2 / 14$ & $4 / 11$ & $7 / 7$ & $2 / 2$ & $2 / 26$ & $4 / 12$ & $4 / 8$ \\
\hline Pyruvic attacked & $0 / 9$ & $9 / 10$ & $2 / 7$ & $0 / 3$ & $6 / 22$ & $2 / 7$ & $8 / 9$ \\
\hline Grow at $45^{\circ} \mathrm{C}$ & $10 / 12$ & $13 / 13$ & $9 / 9$ & $2 / 2$ & $25 / 25$ & $7 / 8$ & $7 / 9$ \\
\hline Grow aerobically & $9 / 16$ & $9 / 13$ & $6 / 9$ & $3 / 3$ & $18 / 27$ & $12 / 12$ & $6 / 9$ \\
\hline Grow in candle jar & $13 / 16$ & $13 / 13$ & $9 / 9$ & $3 / 3$ & $26 / 27$ & $12 / 12$ & $9 / 9$ \\
\hline
\end{tabular}

"Total numbers of strains tested are in parentheses.

${ }^{b}$ Number of strains positive/number of strains tested.

${ }^{\mathrm{C}}$ Broth-disk method (15). Growth in medium containing clindamycin, $1.6 \mu \mathrm{g} / \mathrm{ml}$; penicillin $\mathrm{G}, 2$ units $/ \mathrm{ml}$; and tetracycline, $6 \mu \mathrm{g} / \mathrm{ml}$.

${ }^{i}$ Acid production from substance specified, unless otherwise stated.

of the strains were susceptible to $12 \mu \mathrm{g}$ of chloramphenicol per $\mathrm{ml}$ and $3 \mu \mathrm{g}$ of erythromycin per $\mathrm{ml}$ (Table 3).

The lactic acid produced by all of the strains examined was a racemic mixture. The propor- tions of $L$ to $D$ optical isomers are presented in Table 4. The values for individual strains range from predominantly $\mathrm{L}+$ isomer to predominantly $\mathrm{D}^{-}$, but the majority of the strains produced nearly equal amounts of the two isomers 
TABLE 4. Optical isomers of lactic acid produced by the homology groups of L. acidophilus

Amount of acid that is $\mathrm{L}$ isomer:

\begin{tabular}{lcccccc}
\cline { 2 - 5 } Homology group & $(75+\%)$ & $(60-75 \%)$ & $(40-60 \%)$ & $(40-25 \%)$ & $(30-0 \%)$ & $\begin{array}{c}\text { Total number } \\
\text { of strains }\end{array}$ \\
\hline A-1 & $1^{a}$ & 2 & 4 & 8 & 1 & 16 \\
A-2 & & 5 & 8 & & 13 \\
A-3 & 2 & 1 & & 1 & 9 \\
A-4 & & 7 & 18 & 2 & 3 \\
B-1 & & 5 & 6 & 1 & 27 \\
B-2 & 3 & 3 & 2 & 1 & 9 \\
Other & & & 6 & \\
\hline
\end{tabular}

${ }^{a}$ Number of strains.

or a slight excess of the $\mathrm{D}$ - isomer.

The cell walls from this group of organisms invariably contain glucose, usually contain galactose, and occasionally contain mannose and/ or rhamnose (Table 5). In general, walls from organisms in homology groups A-1 and A-2 contain less glucose than do walls from organisms in the other homology groups, although the amount varied from a trace to $3+$ in these groups. It may be noted also that rhamnose was not found in the cell walls of any member of homology groups A-1 and A-2. In the other groups, rhamnose was present in some strains but not in others; however, it was not possible to correlate its presence clearly with any other characteristic of the strains. None of the strains examined contained diaminopimelic acid in its cell wall; however, the detailed structure of the peptidoglycan was not studied.

GA3PDH. Immunodiffusion experiments with a series of multiple cross-matches were carried out by using cell-free extracts of strains from the six DNA homology groups of $L$. acidophilus. Figure 1 shows the antigenic hierarchy of the various strains and reveals the following order: ATCC 4356 (=VPI 6032) > $1754>1294$ $>6033=$ or $<7960>1784$.

Results obtained from microcomplement fixation experiments agree well with data from immunodiffusion experiments. Table 6 summarizes both the indexes of dissimilarity and immunological distances among the organisms. There appears to be little, if any, antigenic difference between strains 6033 and 7960 when strain 6032 is used as a point of reference. However, significant antigenic differences may actually exist. The degree of heterogeneity within
L. acidophilus can be more fully appreciated by comparing the immunological distances presented in Table 6 with values obtained for $L a c$ tobacillus helveticus ATCC 15009 and Lactobacillus jensenii ATCC 25258 (unpublished data). These two species gave immunological distance values of 33 and 13.9, respectively.

LDH. All of the strains tested exhibited D$\mathrm{LDH}$ activity, and all except 9940, 0328, and 11473 exhibited nicotinamide adenine dinucleotide-dependent L-LDH activity. A summary of the immunological results with L-LDH antiserum and of the relationship between immunological groups and DNA homology groups is shown in Table 7. The antiserum used was prepared against dehydrogenase from Sharpe strain A18 (=VPI 11695) in homology group A-1. Except for strain 11086, there is excellent correlation between the immunological groups based on $\mathrm{LDH}$ and those recognized by homology tests, although there is not necessarily a one-toone relationship between the two groupings. Strains in LDH immunological group I are all in homology groups B-1 and B-2; strains in LDH immunological group II (except 11086) are in homology groups A-2, A-3, and A-4; and LDH immunological group III strains are all in homology group A-1.

\section{DISCUSSION}

The S1 nuclease procedure was used to determine DNA homology values in this study. For homology values up to about 60 or $70 \%$, results with this method are about $20 \%$ lower than those obtained by either the hydroxylapatite or the membrane competition procedures (unpub- 
TABLE 5. Cell wall sugars in L. acidophilus strains

Homology group

Sugars in cell wall hydrolysates

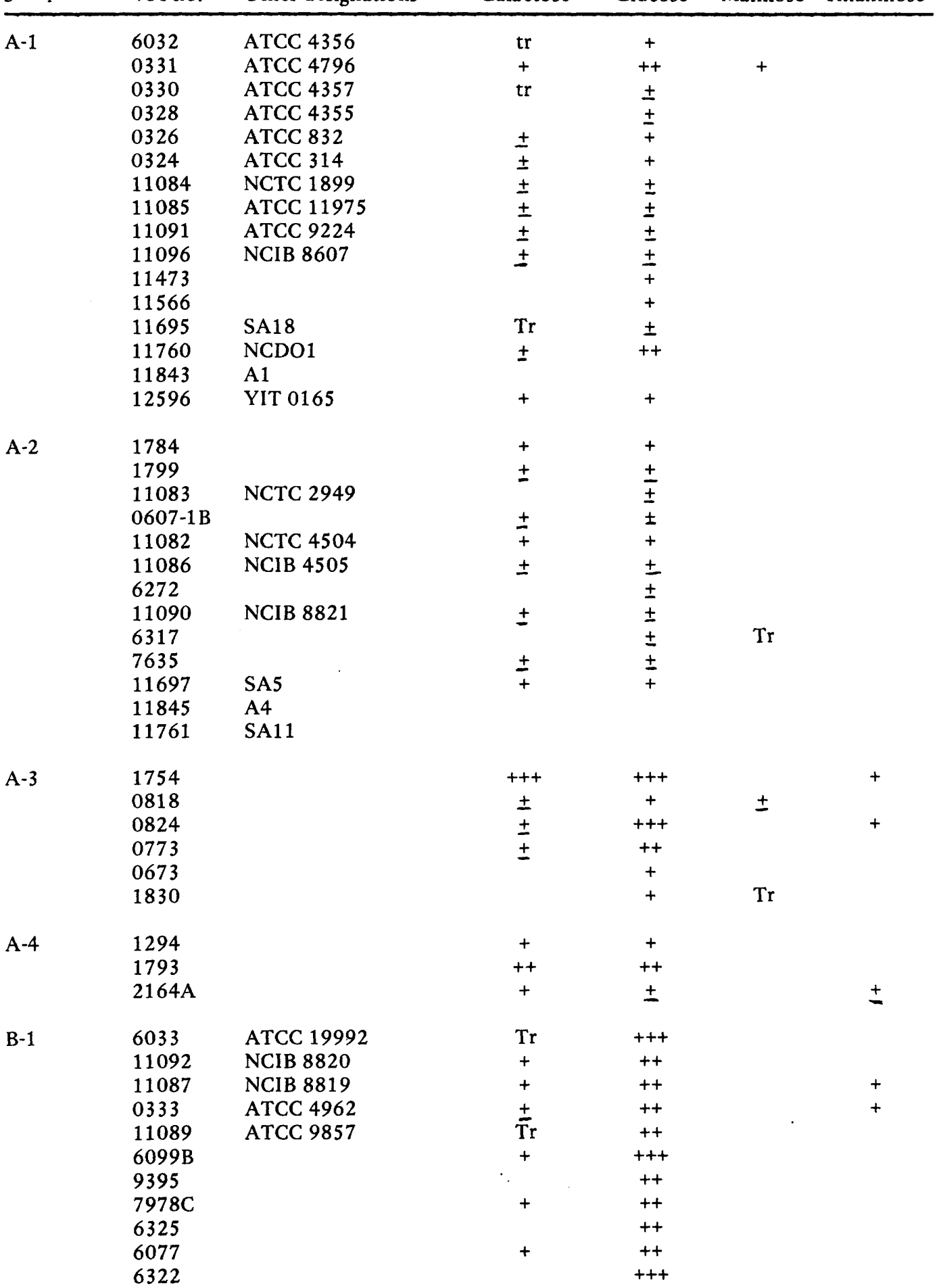


TABLE 5. Continued

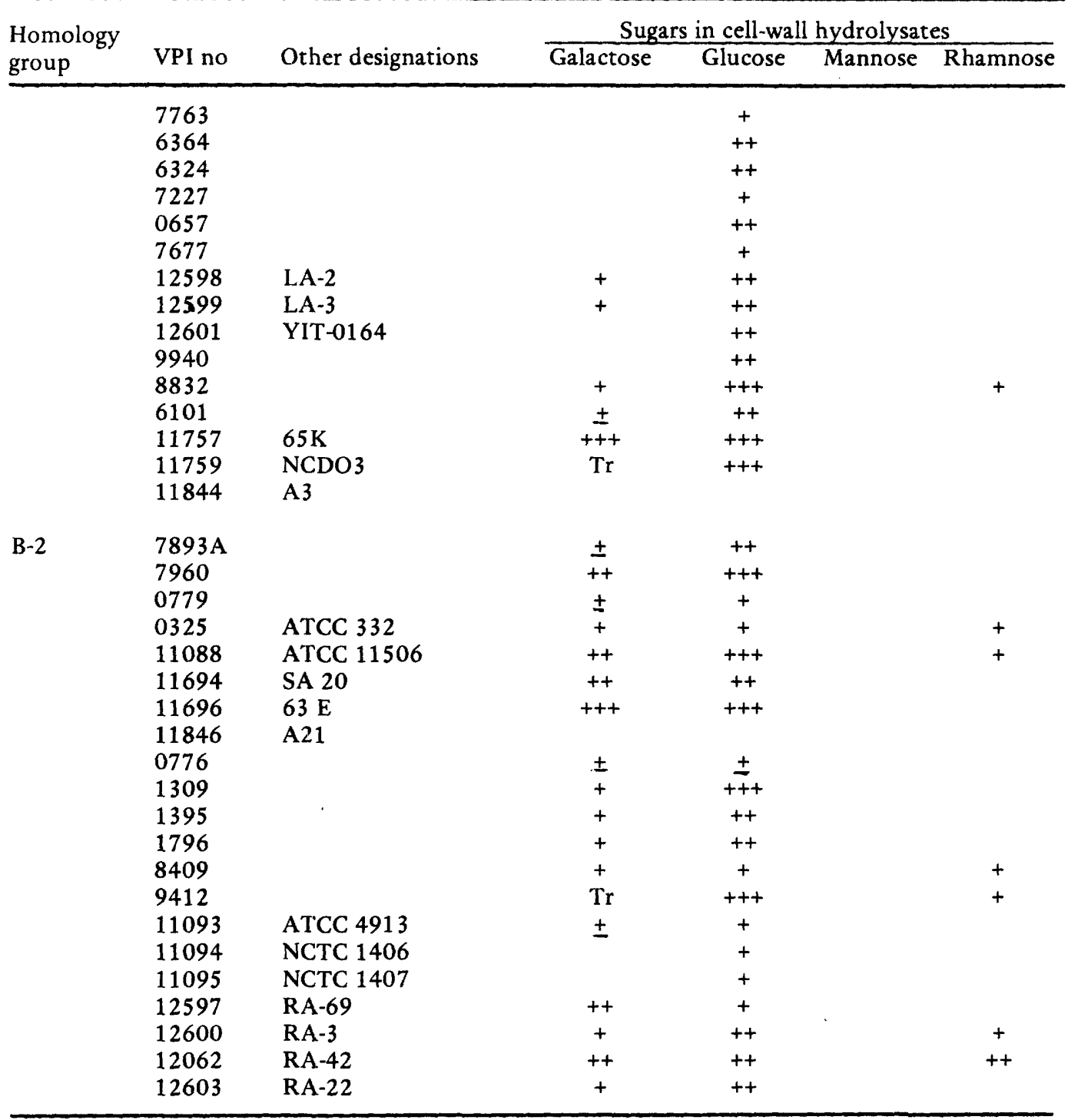

lished data). Differences in the methods are less pronounced with higher ( 80 to $100 \%$ ) homology values. When a comparison is made of the homology results from the $L$. acidophilus group with the homology results from other groups of bacteria $(1,3,19,20,21,27)$, each of the six $L$. acidophilus DNA homology groups could justifiably be designated as a separate species. Homology group A-1, which includes the neotype strain of $L$. acidophilus (ATCC 4356) as the reference strain, is very homogeneous. Most of the strains have greater than 95\% DNA homology to the reference strain. This degree of homogeneity appears to be reflected in the similar- ity of their cell wall antigens (see below) and would explain why this group is easily identified by agglutination and precipitation tests $(6,33)$ (Table 8). Strains in the other DNA homology groups of $L$. acidophilus have from about $60 \%$ to $90 \%$ homology with their reference strains. This heterogeneity is within the range that has been found for most groups of bacteria considered to be single species.

Relationships between DNA homology groups and groups based on physiological tests. Reuter (28) grouped $L$. acidophilus strains into five biotypes, based primarily on variations in the fermentation of trehalose, mel- 
ibiose, and raffinose. Mitsuoka (25) expanded the number of biotypes to 10 by also including variations in the coagulation of litmus milk (fermentation of lactose) and the fermentation of ribose. Eight of the strains used by Reuter and Mitsuoka were included in the present study. The results of physiological tests did not enable us to differentiate among the six DNA homology groups, since the degree of phenotypic heterogeneity within DNA homology groups was essentially the same as that observed among DNA homology groups. We must conclude, therefore, that the use of physiological tests, such as fermentation reactions and growth characteristics, are at present of little value in differentiating the various groups of $L$. acidophilus.

Relationship between homology groups and groups based on cell wall antigens. There have been several attempts to subdivide L. acidophilus by using serological methods; these include agglutination tests by Efthymiou and Hansen, (6) and immunodiffusion tests by Sharpe (32) and Shimohashi and Mutai (33). Some of the strains used in the studies of these authors were also used in the present investigation. The serological results are compared with the homology groups in Table 8. This table also includes the groups based on electrophoretic patterns of $\mathrm{LDHs}$ (7) wherever they have also been determined for the strains.

Sharpe (32 and personal communication) examined a group of 35 strains of $L$. acidophilus,

\begin{tabular}{|c|c|c|c|c|c|}
\hline $4356(A-1)$ & & & & & \\
\hline$\uparrow$ & $1754(\mathrm{~A} \cdot 3)$ & & & & \\
\hline$\uparrow$ & $\uparrow$ & $1294(A-4)$ & & & \\
\hline$\uparrow$ & $\uparrow$ & $\uparrow$ & $6033(\mathrm{~B}-1)$ & & \\
\hline$\uparrow$ & $\uparrow$ & $\uparrow$ & $=\rightarrow$ & 7960 (B-2) & \\
\hline$\uparrow$ & $\uparrow$ & $\uparrow$ & $\uparrow$ & $\uparrow$ & $1784(A-2)$ \\
\hline
\end{tabular}

Fig. 1. Hierarchical arrangement of L. acidophilus strains. Arrows indicate dominant antigen in cross-match. using $\mathrm{HCl}$ extracts of whole organisms. She found two groups which cross-reacted but which could be separated by the use of absorbed sera. However, almost one-half of the strains belonged to neither of these two groups and could not be classified. Sharpe designated the two cross-reacting groups I and II and the unclassified organisms as group III. Group I (10 of 35 strains) corresponds to homology group A-1 (group III of Gasser), and group II of Sharpe seems to correspond to homology group A-2. The two strains in group III of Sharpe (unclassified strains) which were examined in the present investigation both fall into homology group B-2.

Shimohashi and Mutai (33), using antigens extracted by hot dilute $\mathrm{HCl}$ and cold trichloroacetic acid, have also examined a series of $L$. acidophilus strains. Extracts were made from both cell walls and whole cells, and a number of distinct antigens (designated $3,11,12,13$, and 14) were recognized. Antigens $11,12,13$, and 14 were found in both cell wall and whole cell extracts and are therefore presumably cell wall constituents. These four antigens were confined to strains of $L$. acidophilus. Antigen 3 , on the other hand, and another antigen (not named) which was not found in cell walls appear to be rather widely distributed among lactobacilli; they are found not only in $L$. acidophilus but also in strains of $L$. casei, $L$. bulgaricus, $L$. fermentum, $L$. salivarius, $L$. helveticus, and $L$. plantarum.

Eight of the strains of Shimohashi and Mutai were examined in the present investigation, and there is good correlation between the homology groups and the distribution of cell wall antigens, especially antigens 11 and 12 (Table 8). It seems that antigen 12 is characteristic of group A strains and antigen 11 is characteristic of group B strains. Antigens 13 and 14 have so far been found in only a very limited number of strains. Efthymiou and Hansen (6) examined the ag-

TABLE 6. Immunological distances of the L. acidophilus GA3PDHs

\begin{tabular}{lcc}
\hline Strain & $\begin{array}{c}\text { Index of } \\
\text { dissimilarity }\end{array}$ & $\begin{array}{c}\text { Immunologic } \\
\text { distance }\end{array}$ \\
\hline A-1 4356 (6032) & 1.0 & 0 \\
A-3 1754 & $1.26+0.08$ & 10.08 \\
A-4 1294 & $1.44+0.15$ & 15.8 \\
B-1 6033 & $1.99+0.08$ & 29.8 \\
B-2 7960 & $2.02+0.4$ & 30.5 \\
A-2 1784 & $3.45+0.6$ & 53.8 \\
ATCC 15009 & & 33.0 \\
ATCC 25258 & & 13.9 \\
\hline
\end{tabular}


TABLE 7. L-LDH immunological groups of the $L$. acidophilus strains

\begin{tabular}{cc}
\hline VPI strain no. & $\begin{array}{c}\text { Immunologic } \\
\text { group }\end{array}$ \\
\hline
\end{tabular}

Homology group A-1

$\begin{array}{ll}6031 & \text { III } \\ 0331 & \text { III } \\ 0330 & \text { III } \\ 0328 & \text { III } \\ 0326 & \text { III } \\ 0324 & \text { III } \\ 11084 & \text { III } \\ 11473 & \text { III } \\ 11695 & \text { III }\end{array}$

Homology group A-2

1784

11086

6317

7635

III

III

III

III

III

III

III

III

III

Homology group A-3

1754

0824

II

I

II

II

II

II

Homology group A-4 1294

$2164 \mathrm{~A}$

II

II

Homology group B-1

6033

$6099 \mathrm{~B}$

6322

9940

8832

6101

11757

Homology group B-2

7960

0325

11696

glutination reactions of a group of culture collection strains of $L$. acidophilus. They showed that ATCC strains 314, 832, 4356, and 4357 fell into one group serologically; in the present investigation all of these strains were found in homology group A-1. Strain ATCC 4962, which also belonged to this serological group, fell into group B-1 by homology, and it seems possible that the subculture of this strain which we examined was mislabeled. Efthymiou and Hansen also examined two other homology group B strains, ATCC 11506 (homology group B-2) and ATCC 4963 (homology group B-1), and found that these showed no cross-reaction with group A-1 strains. These agglutination results were not included in Table 8 because of the small number of strains involved, but they provide further evidence of the separate identity of homology group A-1 and distinguish it from groups B-1 and B-2.

Relationships between DNA homology groups and groups based on serology of LDH and GA3PDH. The precipitin reactions of the L-LDHs correlated in part with the DNA homology results. Of 27 strains, 26 could be correctly identified as belonging either to DNA homology group A-1, to homology group A-2, A3 , or A-4, or to homology group B-1 or B-2. These results are somewhat less specific than those obtained by Gasser and Hontebeyrie (10, 18 ) in the genus Leuconostoc. They found complete correlation between four serological groups and four DNA homology groups, with intergroup homology values similar to those found in the present study. There appears to be a common set of determinants in the A-2, A-3, and A-4 homology groups that react with the antibody produced against the A-1 strain (strain A18 of Sharpe). Similarly, there appears to be a set of antigenic determinants common to strains from the B-1 and B-2 homology groups which react with the antiserum. We might predict that the use of an antiserum produced against L-LDH from a strain in the A-2 homology group would permit accurate identification of strains in that group, whereas strains in homology groups A-1, $\mathrm{A}-3$, and A-4 would be indistinguishable from each other. One might also predict that the use of antisera to L-LDH from a B-1 strain would distinguish the two $B$ homology groups but would react equally with all A homology groups.

The immunological results with antiserum to GA3PDH from strain VPI 6032 were similar in most cases to those obtained when L-LDH antiserum was used. For example, the immunological distance of the two B strains (6033 [B-1] and 7960 [B-2]) from strain 6032 is considerably greater than the distance of the two A strains (1754 [A-3] and 1294 [A-4]) from 6032. The notable exception was for strain 1784 , which belongs to homology group A-2 and to L-LDH immunological group II. The GA3PDH from this strain appears to be more distantly related to the reference enzyme (strain 6032, homology group A-1) than to the enzymes from organisms in homology groups B-1 and B-2 and from the type strains of $L$. helveticus (ATCC 15009) and Lactobacillus jensenii (ATCC 25258). It is possible that this discrepancy is due to a technical error, but if not, it will be of interest to determine whether it is characteristic of the A-2 homology group in general. The rest of the GA3PDH results correlate with the L-LDH results. This is similar to the complete correlation that was found when D-LDH and glucose-L-phosphate 
TABLE 8. Relationships between homology groups, serologic groups, and electrophoretic pattern of LDH

\begin{tabular}{|c|c|c|c|c|}
\hline Strains & $\begin{array}{l}\text { Homology } \\
\text { group }\end{array}$ & $\begin{array}{l}\text { Antigen no. } \\
\text { (Shimohashi } \\
\text { \& Mutai) }\end{array}$ & $\begin{array}{l}\text { Electrophoretic pattern } \\
\text { of LDH (Gasser) }\end{array}$ & $\begin{array}{c}\text { Antigen group } \\
\text { (Sharpe) }\end{array}$ \\
\hline $\begin{array}{l}\text { ATCC } 4356 \\
\text { ATCC } 4357 \\
\text { Yito } 165 \\
\text { A1 } \\
\text { A18 }\end{array}$ & $\mathrm{A} 1$ & $\begin{array}{l}12 \\
12 \\
12 \\
12\end{array}$ & $\begin{array}{l}\text { III } \\
\text { III } \\
\text { III }\end{array}$ & $\begin{array}{l}\text { I } \\
\text { I } \\
\text { I }\end{array}$ \\
\hline $\begin{array}{l}\text { A4 } \\
\text { A5 } \\
\text { A11 }\end{array}$ & A2 & $\begin{array}{l}13 \\
12\end{array}$ & $\begin{array}{l}\text { II } \\
\text { II } \\
\text { II }\end{array}$ & $\begin{array}{l}\text { II } \\
\text { II } \\
\text { II }\end{array}$ \\
\hline $\begin{array}{l}\text { ATCC } 4963 \\
\text { ATCC } 9857 \\
\text { ATCC } 19992 \\
\text { Yito } 164 \\
\text { LA-2 } \\
\text { LA-3 } \\
\text { NCDO } 3 \\
65 \mathrm{~K}\end{array}$ & B1 & $\begin{array}{l}11 \\
11 \\
11 \\
11 \\
11 \\
11\end{array}$ & $\begin{array}{l}\text { Ib } \\
\text { Ia } \\
\text { Ia }\end{array}$ & \\
\hline $\begin{array}{l}\text { ATCC } 11506 \\
\text { RA-22 } \\
\text { RA-3 } \\
\text { RA-42 } \\
\text { RA-69 } \\
63-E \\
\text { A-20 } \\
\text { A-21 }\end{array}$ & B2 & $\begin{array}{l}11 \\
11 \\
11 \\
11 \\
14\end{array}$ & $\begin{array}{l}\mathrm{Ib} \\
\mathrm{Ib} \\
\mathrm{Ib}\end{array}$ & $\begin{array}{l}\text { III } \\
\text { III }\end{array}$ \\
\hline
\end{tabular}

dehydrogenase were used in the genus Leuconostoc (17).

DNA from $L$. helveticus strain ATCC 15004 has from 13 to $44 \%$ homology to the reference strains of the A homology groups and could be considered another A homology group. It is not surprising that the GA3PDH enzymes have immunological determinants in common. DNA homology between the various $L$. acidophilus reference strains and an $L$. jensenii strain (type strain; ATCC 25258) was hardly detectable, yet the immunological distance between it and $L$. acidophilus strain ATCC 4356 was only 13.9. It appears that the DNA coding for this enzyme is more conserved between these two organisms than is the bulk of the DNA.

Taxonomic recommendations. At the present time we have a number of taxonomic recommendations to make. First, DNA homology group A-1 (immunological group III of Gasser) should be designated $L$. acidophilus and strain ATCC 4356 should remain the neotype strain. This is in agreement with the proposal of Hansen and Mocquot (14). Second, DNA homology group A-2 should be considered a species (unnamed at this time) and strain ATCC 33197 (=VPI 7635) should be designated the type strain. This species would be in immunological group II of Gasser. Third, we recommend that DNA homology groups A-3 and A-4 should not be proposed as separate species until more strains have been investigated. This would allow time for an assessment of their ecological importance. Representatives of these groups are also being deposited with the ATCC. Fourth, we recommend that DNA homology group B-1 be designated a new species (also unnamed at this time). Kandler and his associates have done a similar type of investigation involving some of the same strains which we studied $(0$. Kandler, personal communication). They are proposing to designate as a species a group corresponding to our homology group B-1. This species would be in immunological group I of Gasser. Electron micrographs have revealed that the cell widths of the two B-1 reference strains were only slightly more than one-half the width of the other reference strains (Johnson, unpublished 
data). And finally, DNA homology group B-2 should also be considered a new species (again, unnamed at this time), and strain ATCC 33200 (=VPI 7960) should be designated the type strain. This species would also be in immunological group I.

\section{ACKNOWLEDGMENTS}

We thank W. E. C. Moore for reviewing the manuscript We are indebted to W. E. C. Moore, L. V. Holdeman, and E. P. Cato for providing phenotypic data. We also thank M. E. Sharpe, National Institute for Research in Dairying, University of Reading, Reading, England, for providing unpublished data and several cultures, and $\mathrm{H}$. Shimohashi, Yakult Institute for Microbial Research, Tokyo, Japan, for providing cultures. The technical assistance of Cynthia Gross, Habiba Najafi, Margaret Vaught, and Phyllis Sparks is greatly appreciated.

This work was supported in part by Public Health Service grant GMS 14604 from the National Institute of General Medical Sciences.

\section{REPRINT REQUESTS}

Address reprint requests to: Dr. J. L. Johnson, Anaerobe Laboratory, Virginia Polytechnic Institute and State University, Blacksburg, VA 24061.

\section{LITERATURE CITED}

1. Brenner, D. J., G. R. Fanning, K. E. Johnson, R. V. Citarella, and S. Falkow. 1969. Polynucleotide sequence relationships among members of Enterobacteriaceae. J. Bacteriol. 98:637-650.

2. Champion, A. B., E. M. Prager, D. Wachter, and A. C. Wilson. 1974. Microcomplement fixation, p. 397416. In C. A. Wright (ed.), Biochemical and immunological taxonomy of animals and plants. Academic Press Inc., London.

3. Crosa, J. H., D. J. Brenner, and S. Falkow. 1973. Use of single-strand-specific nuclease for analysis of bacterial and plasmid deoxyribonucleic acid homo- and heteroduplexes. J. Bacteriol. 115:904-911.

4. Cummins, C. S., and J. L. Johnson. 1971. Taxonomy of the clostridia: wall composition and DNA homologies in Clostridium butyricum and other butyric acid-producing clostridia. J. Gen. Microbiol. 67:33-46.

5. Curran, H. R., L. A. Rogers, and E. O. Whittier. 1933. The distinguishing characteristics of Lactobacillus ac. idophilus. J. Bacteriol. 25:595-621.

6. Efthymiou, C., and P. A. Hansen. 1962. An antigenic analysis of Lactobacillus acidophilus. J. Infect. Dis. 110:258-267.

7. Gasser, F. 1970. Electrophoretic characterization of lactic dehydrogenases in the genus Lactobacillus. J. Gen. Microbiol. 62:223-239.

8. Gasser, F., M. Doudoroff, and R. Contopoulos, 1970. Purification and properties of NAD-dependent lactic dehydrogenases of different species of Lactobacillus. J. Gen. Microbiol. 62:241-250.

9. Gasser, F., and C. Gasser. 1971. Immunological relationships among lactic dehydrogenases in the genera Lactobacillus and Leuconostoc. J. Bacteriol. 106:113125.

10. Gasser, F., and M. Hontebeyrie. 1977. Immunological relationships of glucose-6-phosphate dehydrogenase of Leuconostoc mesenteroides NCDO 768 (=ATCC 12291). Int. J. Syst. Bacteriol. 27:6-8.

11. Gasser, F., and M. Mandel. 1968. Deoxyribonucleic acid base composition of the genus Lactobacillus. J. Bacteriol. 96:580-588.

12. Gasser, F., and M. Sebald. 1966. Composition en bases nucleiques des bacteries du genre Lactobacillus. Ann. Inst. Pasteur Paris 110:261-275.
13. Hansen, P. A. 1968. Type strains of Lactobacillus species. A report by the taxonomic subcommittee on lactobacilli and closely related organisms. American Type Culture Collection, Rockville, Md.

14. Hansen, P. A., and G. Mocquot. 1970. Lactobacillus acidophilus (Moro) comb. nov. Int. J. Syst. Bacteriol. 20:325-327.

15. Holdeman, L. V., E. P. Cato, and W. E. C. Moore (ed.) 1977. Anaerobe laboratory manual, 4th ed. Virginia Polytechnic Institute and State University, Blacksburg.

16. Holland, D. F. 1920. Generic index of the commoner forms of bacteria. J. Bacteriol. 5:215-229.

17. Hontebeyrie, M., and F. Gasser. 1975. Comparative immunological relationships of two distinct sets of isofunctional dehydrogenases in the genus Leuconostoc. Int. J. Syst. Bacteriol. 25:1-6.

18. Hontebeyrie, M., and F. Gasser. 1977. Deoxyribonucleic acid homologies in the genus Leuconostoc. Int. J. Syst. Bacteriol. 27:9-14.

19. Johnson, J. L. 1973. Use of nucleic-acid homologies in the taxonomy of anaerobic bacteria. Int. J. Syst. Bacteriol. 23:308-315.

20. Johnson, J. L. 1978. Taxonomy of the Bacteroides. I. DNA homologies among Bacteroides fragilis and other saccharolytic Bacteriodes species. Int. J. Syst. Bacteriol. 28:245-256.

21. Johnson, J. L., and C. S. Cummins. 1972. Cell wall composition and deoxyribonucleic acid similarities among the anaerobic coryneforms, classical propionibacteria, and strains of Arachnia propionica. J. Bacteriol. 109:1047-1066.

22. London, J., and K. Kline. 1973. Aldolase of lactic acid bacteria: a case history in the use of an enzyme as an evolutionary marker. Bacteriol. Rev. 37:453-478.

23. Marmur, J. 1961. A procedure for the isolation of deoxyribonucleic acid from microorganisms. J. Mol. Biol. 3: 208-218.

24. Marmur, J., and P. Doty. 1962. Determination of the base composition of deoxyribonucleic acid from its thermal denaturation temperature. J. Mol. Biol. 5:109-118.

25. Mitsuoka, T. 1969. Vergleichende Untersuchungen uber die Laktobazillen aus den Faeces von Menschen, Schweinen und Huhnern. Zentralbl. Bakteriol. Parasitenkd. Infektionskr. Hyg. Abt. 1 Orig. 210:32-51.

26. Moro, E. 1900. Ueber die nach Gram farbbaren Bacillen des Sauglingsstuhles. Wien. Klin. Wochenschr. 13:114115.

27. Palleroni, N. J., R. W. Ballard, E. Ralston, and $\mathbf{M}$. Doudoroff. 1972. Deoxyribonucleic acid homologies among some Pseudomonas species. J. Bacteriol. 110:111.

28. Reuter, G. 1964. Vergleichsuntersuchungen an 90 thermophilen Laktobacillen-Stammen verschiedener Herkunft. Zentralbl. Bakteriol. Parasitenkd. Infectionskr. Hyg. Abt. 1 Orig. 193:454-466.

29. Rogosa, M., and M. E. Sharpe. 1959. An approach to the classification of lactobacilli. J. Appl. Bacteriol. 22: 329-340.

30. Rogosa, M., R. F. Wiseman, J. A. Mitchell, and N. Disraely. 1953. Species differentiation of oral lactobacilli from man including descriptions of Lactobacillus salivarius nov. spec. and Lactobacillus cellobiosus nov. spec. J. Bacteriol. 65:681-699.

31. Sarich, V. M., and A. C. Wilson. 1966. Quantitative immunochemistry and the evolution of primate albumins: microcomplement fixation. Science 154:15631566.

32. Sharpe, M. E. 1970. Cell wall and cell membrane antigens used in the classification of lactobacilli. Int. J. Syst. Bacteriol. 20:509-518.

33. Shimohashi, H., and M. Mutai. 1977. Specific antigens of Lactobacillus acidophilus. J. Gen. Microbiol. 103: 337-344. 
34. Stollar, D., and L. Levine. 1963. Two-dimensional immunodiffusion. Methods Enzymol. 6:848-854.

35. Tittsler, R. P., D. S. Geib, and M. Rogosa. 1947. Taxonomy of the genus Lactobacillus with special reference to correlation of differential characteristics. J. Bacteriol. 54:12-13.

36. Vogt, V. M. 1973. Purification and further properties of single-strand-specific nuclease from Aspergillus oryzae. Eur. J. Biochem. 33:192-200.

37. Wasserman, E., and L. Levine. 1961. Quantitative micro-complement fixation and its use in the study of antigenic structure by specific antigen-antibody inhibition. J. Immunol. 87:290-295. 